\title{
CONTRIBUTION TO THE VALORIZATION OF MOROCCAN WOOD IN INDUSTRY OF LAMINATED WOOD: CASE OF GROWN EUCALYPTI AND QUERCUS ILEX
}

\author{
Abdelmajid Daya ${ }^{1}$, Abderrahim Famiri ${ }^{2}$, Zitouni Azari ${ }^{3}$ \\ ${ }^{1}$ Laboratoire de Modélisation en Mécanique-Energétique et Systèmes Automatiques (LMMESA), Département de \\ Physique Faculté des Sciences et Techniques Errachidia, Université My Ismaïl, BP 509 Boutalamine, 52000 Errachidia, \\ Morocco \\ ${ }^{2}$ Laboratoire des Essais Physiques et Mécaniques du bois, DREF Charia Omar Ibn Al Khattab, BP 736, 10050 Rabat, \\ Agdal, Morocco \\ ${ }^{3}$ Laboratoire de Mécanique Biomécanique Polymère Structure, Ecole Nationale d'Ingénieur de Metz, Université Paul \\ Verlaine Metz, 1 route d'Ars Laquenexy, 57078 Metz, France
}

\begin{abstract}
The valorization of wood the grown Eucalypti and the Quercus ilex wood known as nervous in the industry of glued laminated wood, benefit are beneficial for the forest industry. A study on the mechanical behavior of tensile specimens of solid wood and glued wood (end-to-end and beveled) and the influence of assembly method on the tensile strength is made. The quality of the assembly is processed by a probabilistic model based on Weibull statistical approach allowing predicting reliability. The Weibull module $m$ of solid wood of both hardwoods is very low compared to that of glued wood.
\end{abstract}

Keywords: Grown Eucalypti, Quercus ilex, solid wood, glued wood, Weibull, reliability, failure

\section{INTRODUCTION}

The wood of grown Eucalypti and Quercus ilex has many defects, from a physical and mechanical point of view [1], which reduce his field of application in industry. The possibilities of transformation of the massive wood of these two species are particularly limited by the release of the growth stress during demolition, slicing, by the development of slits and the problems which occur during drying [2]. Many research showed it, in particular the study of the indicators of constraint of growth GSI [3] and technological characteristics of grown Eucalypti and Quercus ilex [4].

Green and Kretschmann [5], Kretschmann and Green [6] and Green and al.[7] reported that maximum resistance in traction, parallel to the fibre, is reached with a moisture content varying between $10 \%$ and $12 \%$. In addition, the moisture content of wood at the time it is joining must take into account the moisture already present in the adhesive. Indeed, the adhesive and wood moisture will considerably affect the process of damping, of penetration and hardening of this latter. In general, the aqueous adhesives stick in a satisfactory way to moisture contents varying from $6 \%$ to $14 \%$. However, one can use higher ranges of moisture using the adhesives or of the specialized processes [8]. Work on the tenacity of the couples wood adhesive [9] showed that this one depends on the relationship between the elastic properties of the wood turpentine, and those of the pure adhesive.

This article presents a contribution to the valorization of these two nervous species in order to bring technical elements in the bonded adhesive and to lead to a better knowledge of the quality of solid wood and glued wood. The essential goal is to improve and optimize its uses.

\section{MATERIALS AND METHOD}

\subsection{Plant Material}

The plant material used includes three 45 years old trees of Eucalypti grown coming from Sidi Yahia Gharb $30 \mathrm{kms}$ from the town of Kénitra, and three 85 years old trees of the Quercus ilex coming from Ain Kharzouza Azrou. The choice of the trees has been made in a simple and random way. The selected trees are of good strength, homogeneous and do not present any major defect.

A series of 20 specimens per species and tree without defects, in accordance with French Standard NF 51-022 (Fig.1) were made at the laboratory of the Physical Tests and Mechanics of wood in Rabat starting from the boards which have a moisture of $12,5 \%$. The whole assembly is made with polyurethane 
glue provided by the SEDEC company in Temara under a pressure of $0.8 \mathrm{~N} / \mathrm{mm} 2$.
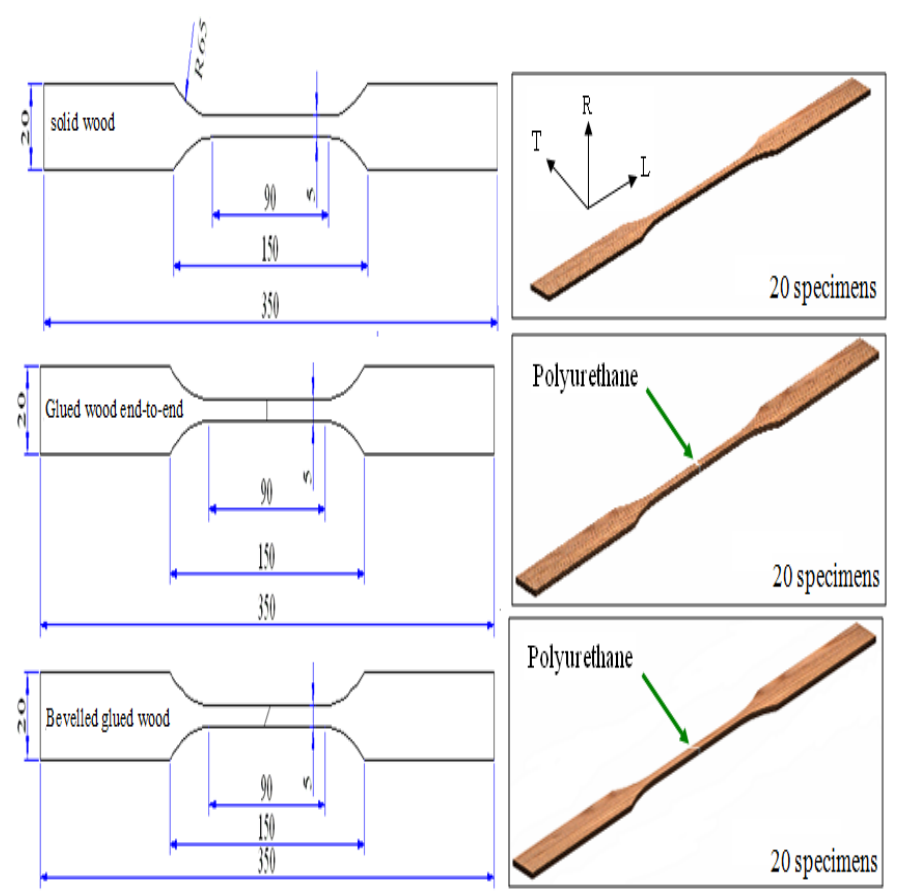

Fig-1: Geometrical characteristics of the tensile specimens.

\subsection{Principle of the Testing}

The tests were carried out on a tensile testing machine TIRA TEST 28300E12 with a capacity of $300 \mathrm{kN}$, controlled by a computer which records the curve load-displacement (Fig.2). The rate of travel of the cross-piece was fixed at $0.5 \mathrm{~mm} / \mathrm{mn}$ for the tensile specimens (solid wood, bevelled glued wood and glued wood end to end),

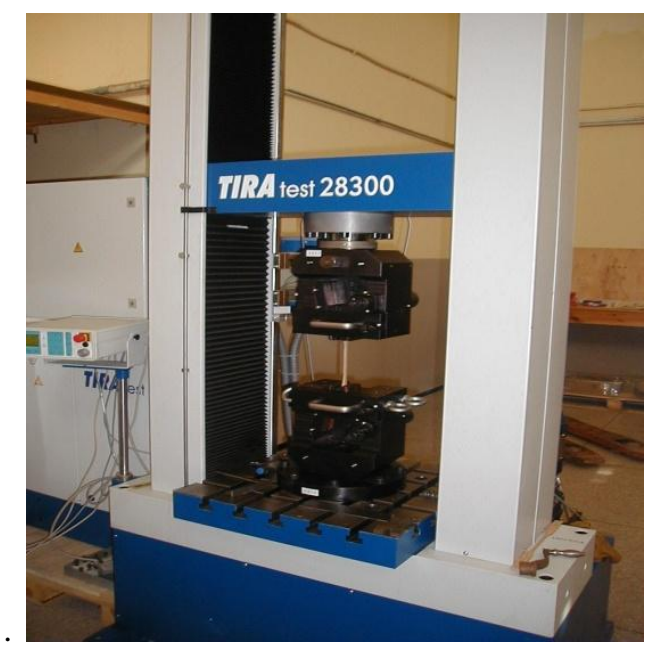

Fig-2: Tensile test

\section{RESULTS}

\subsection{Results of the Tensile Tests}

Fig.3 represents the type of the curve load displacement of grown Eucalypti and Quercus ilex, out of solid wood and glued wood (bevelled end end-to-end ).
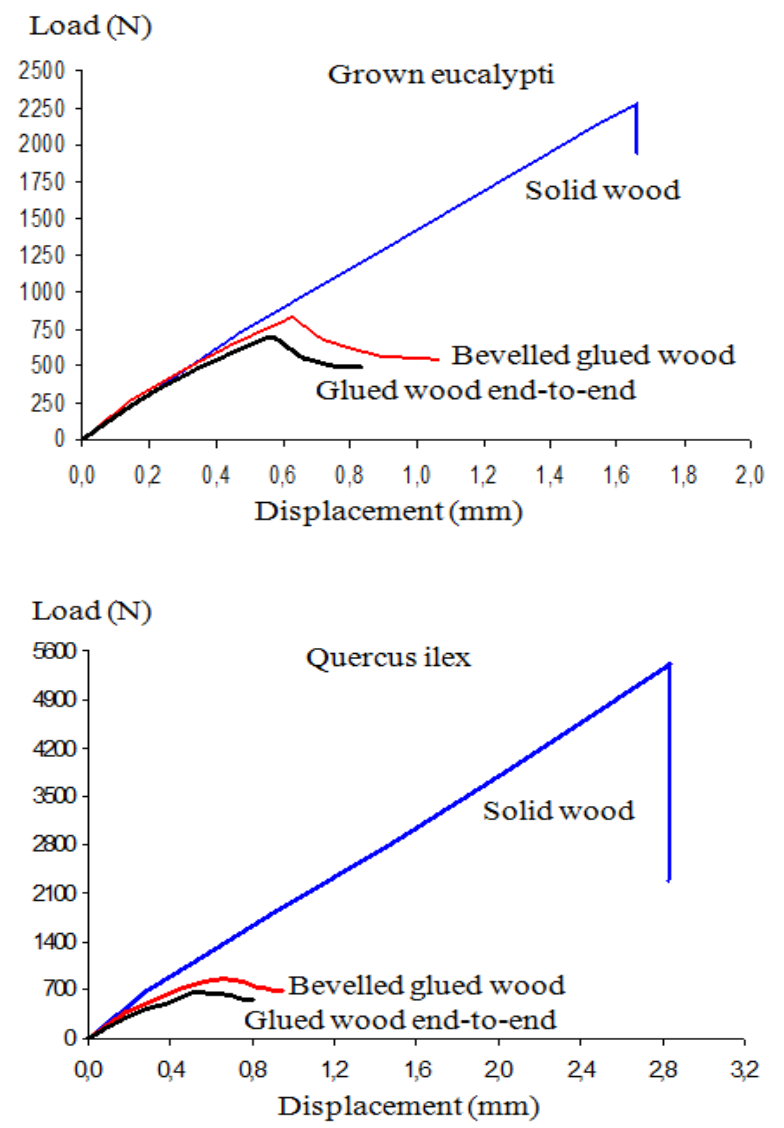

Fig- 3: Behaviour in tensile of solid wood and glued wood (end-to-end and bevelled) of grown Eucalypti and Quercus ilex

The solid wood of the two species presents a mechanical superiority than that of glued wood, in spite of a brittle behavior. The glued wood (end-to-end and bevelled) has a non linear behavior due to the plastification of the adhesive polyurethane (Fig.3).

\subsection{Variability of the Failure Stresses}

Considering the number of tests carried out, wood is a heterogeneous and strongly anisotropic material. We chose the representation in box plot which presents essential information (position, dispersion, and asymmetry) of the breaking stress. The position is that of the box, in particular, horizontal feature which cuts it into two. Dispersion is visualized by the length of the box like by the difference between the limits. Another advantage of the boxes studs is the simultaneous 
representation of the failure stresses of the species and their comparison.

The chart in box stud (Fig.4) has the advantage of comparing variability statistically, between the trees and the species, values of the breaking stress (20 specimens/tree/species) of solid wood and the glued wood (end-to-end and bevelled) of grown Eucalypti and Quercus ilex.
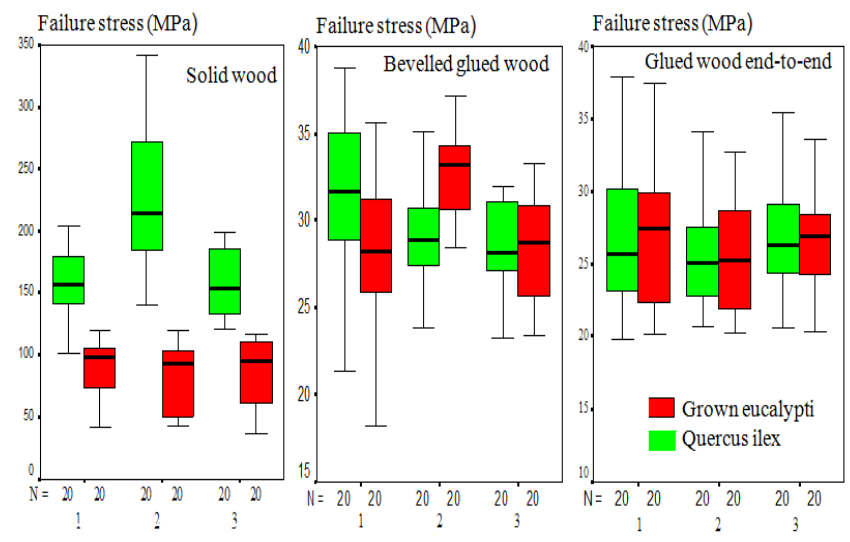

Fig.-4: Chart in box studs of failure stress of solid wood, bevelled wood and end-to-end of grown Eucalypti and Quercus ilex

On the one hand, we note, for solid wood, that failure stress of the Quercus ilex $\left(\sigma_{\mathrm{r}}=181,25 \mathrm{MPa}\right)$ is twice higher than that of grown Eucalypti $\left(\sigma_{\mathrm{r}}=85,42 \mathrm{MPa}\right)$, on the other hand, for glued wood the values are almost identical. This is due to the weak section of the specimens, with the good aptitude of the adhesive polyurethane.

\subsection{Application of the Weibull Model with two}

\section{Parameters}

The statistical model of Weibull with two parameters makes it possible to obtain the probability of rupture of an element according to the state of stress. Failure Probability $(\operatorname{Pr}(\sigma))$ is as follows:

$$
P_{r}(\sigma)=1-\exp \left(-\left(\frac{\sigma}{\sigma_{0}}\right)^{m}\right)
$$

With: $\mathrm{P}_{\mathrm{r}}(\sigma)$ : Failure Probability

$\sigma_{0}$ : Factor of standardization

$\mathrm{m}$ : Module of Weibull

Table.1 gathers the parameters of the law of Weibull for the wood of grown Eucalypti and the Quercus ilex. The distribution has two parameters.
Table-1: Parameters of the law of Weibull of the wood of grown Eucalypti and the wood of Quercus ilex for the distribution with two parameters.

\begin{tabular}{|c|c|c|c|c|c|c|}
\cline { 2 - 7 } \multicolumn{1}{c|}{} & \multicolumn{2}{c|}{$\begin{array}{c}\text { Glued wood } \\
\text { end-to-end }\end{array}$} & \multicolumn{2}{c|}{$\begin{array}{c}\text { Bevelledglued } \\
\text { wood }\end{array}$} & \multicolumn{2}{c|}{$\begin{array}{c}\text { Solid } \\
\text { wood }\end{array}$} \\
\hline Species & $\begin{array}{c}\text { E. } \\
\text { grown }\end{array}$ & $\begin{array}{c}\text { Quercus } \\
\text { ilex }\end{array}$ & $\begin{array}{c}\text { E. } \\
\text { grown }\end{array}$ & $\begin{array}{c}\text { Quercu } \\
\text { s ilex }\end{array}$ & $\begin{array}{c}\text { E. } \\
\text { grown }\end{array}$ & $\begin{array}{c}\text { Quercu } \\
\text { s ilex }\end{array}$ \\
\hline $\mathrm{m}$ & 7,12 & 7,80 & 9,19 & 9,68 & 3,48 & 6,26 \\
\hline$\sigma_{0}$ & 28,09 & 28,11 & 31,31 & 30,94 & 94,98 & 194,93 \\
\hline$\sigma_{\text {moy }}$ & 26,37 & 26,53 & 29,68 & 29,42 & 85,42 & 181,25 \\
\hline
\end{tabular}

$\sigma_{\text {moy }}$ : average of failure stress, $\sigma_{0}$ : factor of standardization and m: module of Weibull

The solid wood of grown Eucalypti and Quercus ilex respectively present a great dispersion in terms of values of the measured failure stresses. The module of Weibull (m) of solid wood with a very weak average is compared with glued wood. The factor of standardization is slightly higher than the average of failure stress which is an intrinsic parameter of each essence

\subsection{Superposition Failure Reliability}

Contrary to reliability, the failure $\mathrm{Q}$ evolves in the opposite direction of $\mathrm{R}$ and represents the failure probability.

$$
Q(\sigma)=1-R(\sigma)=\exp \left(-\left(\frac{\sigma}{\sigma_{0}}\right)^{m}\right)=P_{r}(\sigma)
$$

The superposition of the failure curve and the reliability curve conversely shows the situation at the point of intersection of the two curves (Fig 5). This point results in $\mathrm{R}=\mathrm{Q}=0,5$, whose ratio of the failure stress and factor of standardization are given by table 2 .

Table- 2: Failure stress on the factor of standardization to $\mathrm{R}=$ $\mathrm{Q}=0,5$

\begin{tabular}{|c|c|c|c|}
\hline$\sigma / \sigma_{0}$ & $\begin{array}{c}\text { Solid } \\
\text { wood }\end{array}$ & $\begin{array}{c}\text { Bevelled } \\
\text { glued wood }\end{array}$ & $\begin{array}{c}\text { Glued wood } \\
\text { end-to-end }\end{array}$ \\
\hline $\begin{array}{c}\text { grown } \\
\text { Eucalypti }\end{array}$ & 0,900 & 0,961 & 0,950 \\
\hline Quercus ilex & 0,943 & 0,963 & 0,954 \\
\hline
\end{tabular}

The solid wood of grown Eucalyptus reached the point of intersection before that of glued wood (Fig.5), this be explained by the bevelled and end-to-end bonded which improves the reliability of the glued system. 


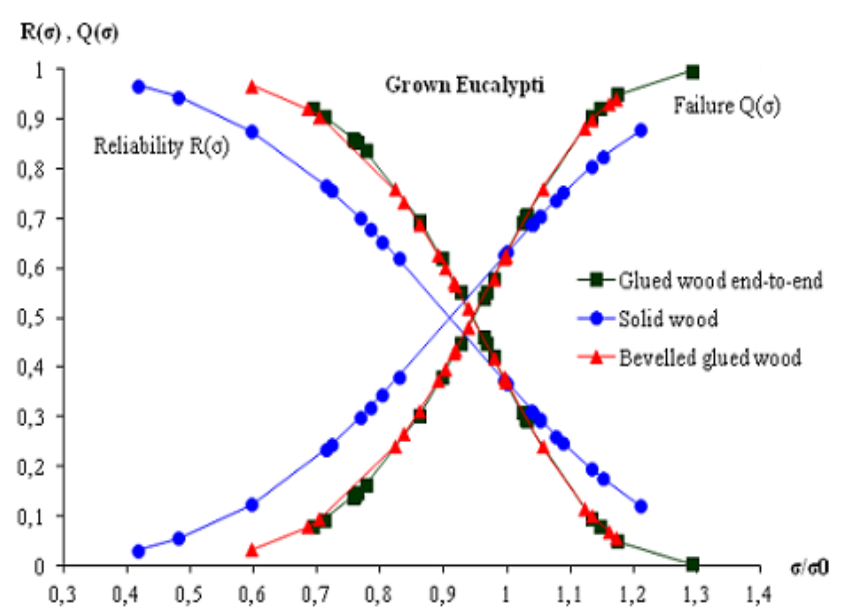

Fig-5: Superposition of the curves of reliability and failure of grown Eucalypti

Solid wood and glued wood of Quercus ilex will reach the point of intersection at the same time (Fig.6), this means that the assembly glued end-to-end and bevelled has a reliability similar to that of massive wood.

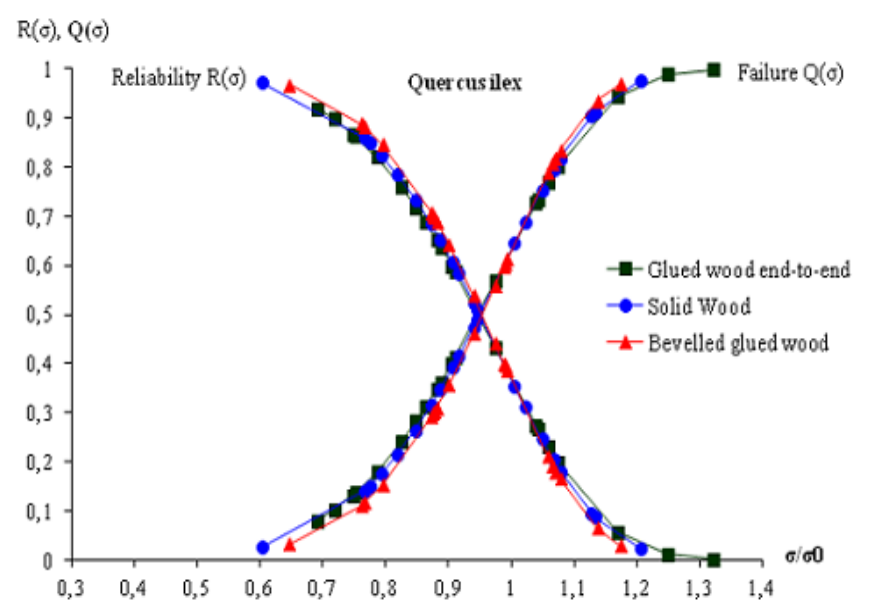

Fig-6: Superposition of the curves of reliability and failure of Quercus ilex

The point of inversions of situation is defined as $\mathrm{Q}(\sigma)=\mathrm{R}(\sigma)$ $=0,5$ which translates the value of survival that solid wood and glued wood can have in terms of reliability of assembly when the ratio of the stresses reaches the value:

$$
\left(\frac{\sigma}{\sigma_{0}}\right)=(\log 2)^{\frac{1}{m}}
$$

Hence the interest of an industrial use of these two nervous essences in Morocco (a great plasticity, a failure stress important, economy)

\subsection{Nature and Type of Break}

For solid wood and end-to-end glued wood, we are in the presence of a tensile fracturing. The normal stress controls this mode of failure. For the bevelled glued wood, one tangential stress which associates at the same time tensile and shearing (Fig.7). The fracturing type is cohesive: in the seal of the adhesive, for glued wood (end-to-end and bevelled) and in the wood for the solid wood.

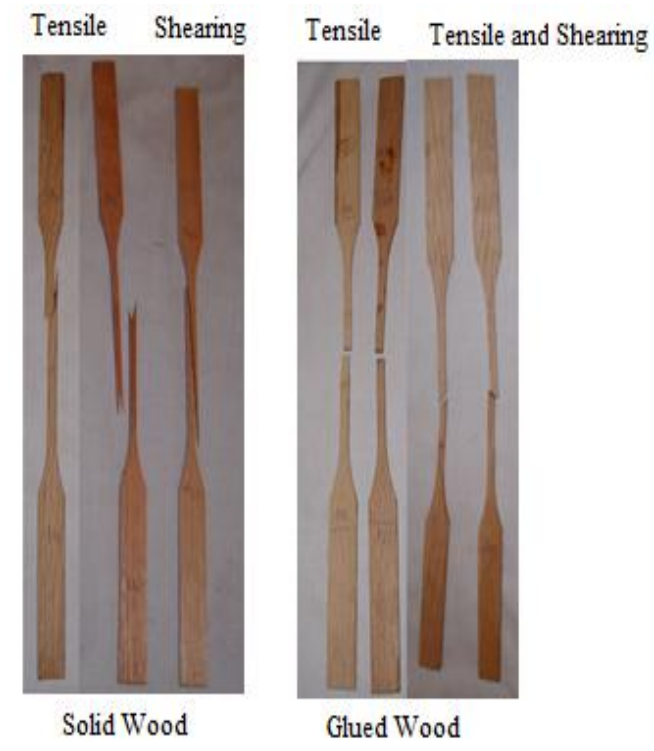

Fig-7: Nature and type break

\section{CONCLUSIONS}

Within the framework of the valorization of national wood, in particular of nervous woods of grown eucalypti and Quercus ilex, we have compared the failure stress and the fracture toughness of solid wood and glued wood.

The solid wood of grown Eucalypti and the Quercus ilex respectively present a great dispersion of the breaking stresses at traction compared to the bevelled or end-to-end glued wood which results in a weak module of Weibull $\mathrm{m}$. This module can be a parameter of dimensioning of the assemblies and it is similar to the security factor, since joining minimizes dispersion in terms of failure stress.

The reliability of glued wood is slightly higher than the solid wood of Eucalypti grown and almost similar to the reliability of the Quercus ilex wood. The solid wood for these species is tougher than for glued wood.

The bonded assembly could be a solution for these two nervous leafy trees which are considered as difficult. These two essences occupy a large interest of establishment in Morocco and enter a policy of valorization (average rigidity) to minimize the importation of wood coming from abroad 
such as silver fir normally used in industry of glued laminated.

\section{REFERENCES}

[1]. A. Daya, M. Chergui, A .Famiri, P. Jodin, Z. Azari, M. Elghorba, Etude comparative de quelques propriétés physiques et mécaniques des bois d'eucalyptus grandis et de chêne vert. $7^{\text {ème }}$ Congrès de Mécanique, 19-22 avril2005. Casablanca, Maroc.

[2]. A. Famiri, Contribution à la caractérisation et à la valorisation du bois de la forêt marocaine. Cas des eucalyptus et du chêne vert. Thèse d'état es-sciences physique, Université Mohamed V, Rabat. 2005.

[3]. A. Daya, M. Chergui, M. Elghorba, A. Famiri, Valorisation des petits bois d'eucalyptus par aboutage à entures multiples: Approche statistique. $6^{\text {eme }}$ Congrès de Mécanique, Tanger 2003, p.218-219.

[4]. K. Anbari,. Nouvelles utilisations du bois d'eucalyptus camaldulensis sous forme de bois collé. Thèse en Sciences Physiques, Université Hassan II, Casablanca, 2003.

[5]. D.W. Green, D.E. Kretschmann, Moisture content and the properties of clear Southern pine. Res. Pap. FPL-RP-531. USDA Forest Serv., Prod. Lab., Madison, WI. EU. 28pp. 1994.

[6]. D.E. Kretschmann, D.W. Green, Moisture content-specific gravity relationships for clear Southern pine. Dans: Proceedings of the international wood engineering conference. Édité par Gopu, Vijaya K.A. 28-31 Octobre 1996. NouvelleOrléans, LA. EU. Vol.2. pp. 536-542.

[7]. D.W. Green, S.M. Cramer, B. Suryoatmono, D.E. Kretschmann,. On fracture-related causes for reduction in tensile strength of Southern Pine lumber at low moisture content. Wood Fiber Sci, 2003a. 35(1):90-101

[8]. A. Daya, A. Famiri, M. Chergui, M. Elghorba, B. Kabouchi. Study of growth stresses in Grown Eucalypti and Holm oak trees. PCN Journal. , 2006, Volume 31, Septembre [9]. A. Daya, M. Chergui,A. Famiri, P. Jodin, Z. Azari, Étude des contraintes de croissance et la résistance à la fissuration des bois d'Eucalyptus grandis et de chêne vert. $18^{\text {ème }}$ Congrès Français de Mécanique, 2007, 27-31 août Grenoble, France. 